\title{
Evaluation of Different Methods for Conversion of Whole Virion Particle (146S) of FMDV into 12S Subunits and Application in Characterization of Monoclonal Antibodies
}

\author{
Gollapalli Sivarama Krishna, S. Shanmuganathan, R. Manikandan, \\ Madhusudhan Hosamani, V. Bhanuprakash, R.P. Tamilselvan, \\ Suresh H. Basagoudanavar, Anikhet Sanyal and B.P. Sreenivasa*
}

Indian Veterinary Research Institute, Hebbala, Bangalore-560024, India

*Corresponding author

\begin{tabular}{|l|}
\hline Ke y w o r d s \\
$\begin{array}{l}\text { Foot-and-mouth } \\
\text { disease virus, } \\
\text { Monoclonal } \\
\text { antibodies, Whole } \\
\text { virion particle, 12S } \\
\text { Subunits }\end{array}$ \\
\hline Article Info \\
\hline $\begin{array}{l}\text { Accepted: } \\
\text { 12 July } 2019 \\
\text { Available Online: } \\
\text { 10 August } 2019\end{array}$ \\
\hline
\end{tabular}

\section{Keywords}

Foot-and-mouth disease virus,

Accepted:

12 July 2019

10 August 2019

\section{A B S T R A C T}

Foot-and-mouth disease (FMD) is a highly contagious disease of cloven hoofed animals caused by FMD virus classified under genus Apthovirus and Picornaviridae family. Monoclonal antibodies (mAb) to FMDV provides best tool for the development of reliable diagnostics and there is a need for the development of $\mathrm{mAbs}$ that specifically recognize either $146 \mathrm{~S}$ or $12 \mathrm{~S}$ for the quality control analysis of FMDV vaccines. In the present study, we developed mAbs specific to FMDV serotype $O$ and characterized their specificity in recognition of $146 \mathrm{~S}$ or $12 \mathrm{~S}$ particles. Three different methods were evaluated for the conversion of $146 \mathrm{~S}$ into $12 \mathrm{~S}$ subunits that includes heat method, strong acid and mild acid methods for testing the reactivity of mAbs with these antigens by double antibody sandwich ELISA. Mild heating of $146 \mathrm{~S}$ antigens at $56^{\circ} \mathrm{C}$ for 1 hour and treatment of $146 \mathrm{~S}$ antigen with weak acid $\left(0.5 \mathrm{M} \mathrm{NaH}_{2} \mathrm{PO}_{4}, \mathrm{pH} 4.5\right.$ - 5.5) resulted in complete conversion of $146 \mathrm{~S}$ into $12 \mathrm{~S}$. Where as in strong acid method $(1 \mathrm{~N} \mathrm{HCl}$ with $\mathrm{pH}$ below 4.5$), 146 \mathrm{~S}$ treated with $1 \mathrm{~N} \mathrm{HCl}$ resulted in loss of antigenicity of $12 \mathrm{~S}$ subunits that reflected in absence of reactivity in ELISA. This may mislead to consider the mAb as $146 \mathrm{~S}$ specific. This study revealed that $\mathrm{mAb}$ binding epitopes of all monoclonals are commonly shared among $146 \mathrm{~S}$ and $12 \mathrm{~S}$ antigens. Further it helps in understanding the specificity of mAbs to $146 \mathrm{~S}$ and $12 \mathrm{~S}$ particles which will be useful for application of mAbs in different diagnostic assays.

\section{Introduction}

Foot-and-Mouth disease is a highly contagious, transboundary and emerging disease of wild and domesticated cloven hoofed animals. The etiological agent is a foot-and-mouth disease virus classified under the genus Apthovirus, Picornaviridae family. Total seven antigenically distinct serotypes were identified viz. O, A, C, Asia1, SAT-1, 2 and 3. Multiple genotypes and lineages are exists under each serotype. The Indian subcontinent consists of higher number of susceptible animal population, hence the disease is endemic in India. The serotypes $\mathrm{O}$, A and Asial are more prevalent in India. As per the 2017-18 annual reports, majority of FMDV outbreaks in India are involved with 
serotype $\mathrm{O}$ followed by Asia 1 and A (ICARDFMD Annual report, 2017-18).

The FMD virus consists of a single stranded positive sense RNA genome that encodes for four structural proteins VP1, VP2, VP3 and VP4 and eight non-structural (NSPs) 2A, 2B, 2C, 3A, 3B, 3Cpro, 3D (RNA dependent RNA polymerase) (Mason et al., 2003; Carrillo et al., 2005). The virion capsid is formed by four structural proteins VP1-4, where the capsid proteins VP1, VP2 and VP3 are exposed on the surface of the capsid while the VP4 lies internally. Each protomer of the capsid consists of proteins VP1, VP2 and VP3, five of such protomers forms a pentameric structure.

These pentameric structures have a sedimentation coefficient of $12 \mathrm{~S}$, hence so called 12S subunits (Denoya et al., 1978, Sanger et al., 1978). Twelve of these pentamers assembled to form an intact virion particles which have a sedimentation coefficient of $146 \mathrm{~S}$ (146S particles) and identified as the highly immunogenic component (Doel et al., 1982). The antigenic sites present on these intact virion particles are responsible for developing immune response in the natural hosts. The $12 \mathrm{~S}$ particles are poorly immunogenic when compared to that of intact $146 \mathrm{~S}$ antigens. However most of the epitopes are commonly shared between both $146 \mathrm{~S}$ antigen and $12 \mathrm{~S}$ antigens. Hence most of the monoclonal antibodies and polyclonal antibodies are cross reactive to both $146 \mathrm{~S}$ and $12 \mathrm{~S}$ antigens. The specificity of mAbs in recognition of epitopes present on $146 \mathrm{~S}$ or $12 \mathrm{~S}$ or both is an essential feature for considering the feasibility of a mAbs in developing a diagnostic assay.

It had been known for several years that mild heating of the $146 \mathrm{~S}$ particles or lowering the $\mathrm{pH}$ of the buffer below 6.5 will disrupt the intact $146 \mathrm{~S}$ into $12 \mathrm{~S}$ subunits. The presence of high density of Histidine (which have a pKa of 6.8) residues at interphase of VP2 and VP3, are identified as the amino acids responsible triggering electrostatic repulsion between protonated imidazoles that led to dissociation of $146 \mathrm{~S}$ to subunits (Acharya et al., 1989). Two of these histidine residues were identified at VP3-141 and VP3-144 in inter-pentameric junction as potential destablilizers. Because these histidine, lysine and arginine residues greatly exceeds the number of negatively charged aspartic acid and glutamic acid residues at inter-pentameric interface, resulting in electrostatic repulsion at $\mathrm{pH}$ below 6.5. Moreover these residues are highly conserved among all the serotypes of FMDV.

The conversion of $146 \mathrm{~S}$ particles into $12 \mathrm{~S}$ subunits can be done by different methods viz. heat method and acid method. In heat method, the $146 \mathrm{~S}$ particles heated at $56^{\circ} \mathrm{C}$ for 1 hour will led to the complete conversion of $146 \mathrm{~S}$ to $12 \mathrm{~S}$ subunits (Harmsen et al., 2015). In acid method, citrate phosphate buffer, sodium phosphate buffer and hydrochloric acids were used for conversion of $146 \mathrm{~S}$ to $12 \mathrm{~S}$ (Barnett $e t$ al., 1989; Samir et al.,2008; Crowther et al., 1982; Smit saart et al.,1990; Steve et al., 1986; Rao et al., 1994; Yang et al., 2007). However, in all acid methods the $\mathrm{pH}$ plays the critical role and need to maintain at $\mathrm{pH} 4.5$. In addition, traditionally sucrose density gradient ultracentrifugation methods were also used for extraction of $12 \mathrm{~S}$ particles (McCullough et al., 1982).

In the present study, monoclonal antibodies were raised with FMDV serotype $O$ and characterized the specificity of monoclonal antibodies in recognition of either $146 \mathrm{~S}$ or $12 \mathrm{~S}$ or both antigens. For this purpose, we evaluated three different methods, heat method and acid methods (strong acid and weak acid) for efficient conversion of $146 \mathrm{~S}$ antigen into $12 \mathrm{~S}$ subunits. Using these antigens in a double antibody sandwich 
ELISA (DAS ELISA), the specificity of mAbs in binding to $146 \mathrm{~S}$ and $12 \mathrm{~S}$ particles were characterized.

\section{Materials and Methods}

\section{Production of $146 S$ antigen}

The FMDV virus serotype O (R2/1975) strain available at Indian Veterinary Research Institute, Bengaluru was cultivated in bulk quantities, inactivated by Binary ethylene imine and concentrated by PEG-6000 method. The concentrated antigen was purified by $\mathrm{CsCl}$ ultracentrifugation method at $1,00,000 \mathrm{~g}$ for overnight and the purified 146S antigen was dialyzed against PBS (pH 7.6). The concentration of the $146 \mathrm{~S}$ antigen was estimated by multiplying the OD at $259 \mathrm{~nm}$ with the extinction factor 131. The purified $146 \mathrm{~S}$ antigen aliquots were prepared as per requirement and stored at $-80^{\circ} \mathrm{C}$ until use.

\section{Development of monoclonal antibodies}

The $146 \mathrm{~S}$ antigen was immunized into 6 weak old Balb/C mice with a concentration of $20 \mu \mathrm{g} / \mathrm{mice}$ with Fruends complete adjuvant through intra-peritoneal route. This was followed by booster doses at regular intervals of 30days with Freunds incomplete adjuvant. The immunized mice sera were screened in DAS ELISA for sufficient serum titres in comparison to that of Guinea pig polyclonal sera. Prior to fusion experiment three consecutive doses of $146 \mathrm{~S}$ antigen were given intra-venously. The mice was sacrificed, spleenocytes were harvested and the fusion of spleenocytes with SP2/0 myeloma cells were carried as per the standard polyethylene glycol method. The supernatant from parental hybridomas were screened for their reactivity with $146 \mathrm{~S}$ antigen by DAS ELISA. From reactive parental hybridomas, single cell clones secreting mAbs were developed by limiting dilution method.

\section{Conversion of $146 S$ into $12 S$ by heat method}

The $146 \mathrm{~S}$ antigen with a concentration of $5 \mu \mathrm{g}$ in $0.5 \mathrm{ml}$ PBS ( $\mathrm{pH} 7.6$ ) was heated at $56^{\circ} \mathrm{C}$ for 1hour in a circulating water bath. After incubation the antigens were diluted in $5 \mathrm{ml}$ of DPBS (pH7.6) and used immediately in ELISA at a concentration of 50ng per well.

\section{Conversion of $146 \mathrm{~S}$ into $12 \mathrm{~S}$ by acid method}

In acid method we used one strong acid, $1 \mathrm{~N}$ $\mathrm{HCl}$ and one weak acid, $0.5 \mathrm{M} \mathrm{NaH}_{2} \mathrm{PO}_{4}$ for conversion of $146 \mathrm{~S}$ into $12 \mathrm{~S}$. In strong acid method $10 \% \mathrm{v} / \mathrm{v}$ of $1 \mathrm{~N} \mathrm{HCl}$ was added to $5 \mu \mathrm{g}$ of antigen in a total volume of $0.5 \mathrm{ml}$, adjusted the $\mathrm{pH}$ to 4.5 with $1 \mathrm{~N} \mathrm{NaOH}$ and incubated at room temperature for 30 minutes. The $\mathrm{pH}$ of the antigen was brought down to 7.6 using $1 \mathrm{M}$ Tris and dissolved in 5ml of DPBS pH7.6 and used immediately in ELISA. In weak acid method, $0.5 \mathrm{M}$ of $\mathrm{NaH}_{2} \mathrm{PO}_{4}$ was added to $5 \mu \mathrm{g}$ of $146 \mathrm{~S}$ antigen in a total volume of $0.5 \mathrm{ml}$ and incubated at room temperature for 30minutes. After adjusting the $\mathrm{pH}$ to 7.6 with $1 \mathrm{~N} \mathrm{NaOH}$, the antigen was dissolved in $5 \mathrm{ml}$ of DPBS and used immediately in ELISA.

\section{Combination of heat and acid methods}

In this method, after addition of acids to the antigen as mentioned above, the samples were heated at $56^{\circ} \mathrm{C}$ for 15 minutes followed by adjusting the $\mathrm{pH}$ to 7.6 , dissolved in $5 \mathrm{ml}$ of DPBS and used immediately in ELISA.

\section{Standardization of double antibody sandwich ELISA (DAS ELISA) for identification of specific reactivity of monoclonals with $146 S$ and $12 S$ antigens}

The 96-well ELISA plates (Nunc, Maxisorb) were coated with 1:8000 dilution of antiFMDV polyclonal Rabbit sera in carbonate 
bicarbonate buffer (pH-9.6) and incubated at $4^{0} \mathrm{C}$ for overnight. The plates were washed thrice with wash buffer (PBS + Tween 20, pH 7.6). The antigens (146S \& 12S) were added to the plates at a concentration of 50ng/well in $50 \mu \mathrm{l}$ and incubated at $37^{\circ} \mathrm{C}$ for 1 hour. After washing the plates for thrice with wash buffer, the monoclonal antibodies were added to respective wells and incubated at $37^{\circ} \mathrm{C}$ for 1hour. At the end of incubation, the plates were washed thrice and anti-mouse HRPO conjugate prepared in 1:4000 dilution in wash buffer was added $50 \mu 1$ per well. The plates were incubated at $37^{\circ} \mathrm{C}$ for 45 minutes. The plates were washed thrice in wash buffer and O-phenylene diamine with $\mathrm{H}_{2} \mathrm{O}_{2}$ substrate was added to the plates and incubated at $37^{\circ} \mathrm{C}$ for 15 minutes. The colored reaction was stopped by adding $1 \mathrm{M} \mathrm{H}_{2} \mathrm{SO}_{4}$. Immediately the optical density reading was taken in a automated ELISA reader at 492-620nm wave length. The data was transformed into preformed excel sheet and analyzed for percentage reactivity of mAbs with $146 \mathrm{~S}$ and $12 \mathrm{~S}$ antigens.

\section{Results and Discussion}

\section{Purification of $146 S$ antigen}

The FMDV serotype $\mathrm{O}$ virus produced in bulk quantities was inactivated and concentrated by standard methods. The purification of $146 \mathrm{~S}$ antigen was done in linear gradient of $\mathrm{CsCl}$ density ultracentrifugation method revealed a clear band at F4 fraction of the gradient. The ratio of OD at $259 \mathrm{~nm}$ and $239 \mathrm{~nm}$ was close to 1.40 for the fraction $\mathrm{F} 4$, confirming the sedimentation coefficient of purified antigen, which is expected close to $140 \mathrm{~S}$. The spectrogram revealed a smooth curve with two peaks which reflects the purity of the $146 \mathrm{~S}$ antigen in that particular fraction (Fig. 1). The antigen concentration per $\mathrm{ml}$ of fraction was estimated by multiplying the OD at $259 \mathrm{~nm}$ with extinction factor 131. The antigen concentration of the fraction was estimated as
$255 \mu \mathrm{g} / \mathrm{ml}$. This purified antigen was used throughout the study for immunization of mice, screening of hybridomas, for preparation of $12 \mathrm{~S}$ subunits and in DAS ELISA.

\section{Production of monoclonal antibodies}

The titration of immunized mice sera prior to fusion revealed sufficient sera titres in comparison to that of Guinea pig polyclonal sera (Fig. 2). Total 61 parental hybridomas were obtained from which 85 single cell clones secreting monoclonal antibodies were developed. The figure 3 represents the reactivity of 85 monoclonals with the cell culture virus antigen in DAS ELISA which confirming the reactivity of all monoclonals with serotype $\mathrm{O}$ cell culture antigen.

\section{Evaluation of different methods for conversion of $146 \mathrm{~S}$ antigen into $12 \mathrm{~S}$ subunits}

The intact whole virion particles (146S), consist of four structural capsid proteins VP1, VP2, VP3, and internally located VP4. Mild heat treatment or lowering the $\mathrm{pH}$ below 6.5 resulted in dissociation of intact virion particles into 12 pentameric subunits, which have a sedimentation coefficient of $12 \mathrm{~S}$, so called $12 \mathrm{~S}$ subunits. In the present study, three different methods were evaluated for efficient conversion of $146 \mathrm{~S}$ antigen into $12 \mathrm{~S}$ sub units. In heat method, mild heating of $146 \mathrm{~S}$ antigen was done at temperature $56^{\circ} \mathrm{C}$ for 1 hour. The antigen was captured by rabbit anti FMDV serotype $\mathrm{O}$ polyclonal coating sera and tested the reactivity of mAbs with captured $12 \mathrm{~S}$ antigen in ELISA. The results indicated that all mAbs are equally reacting to both $146 \mathrm{~S}$ and $12 \mathrm{~S}$ antigens prepared by heat method, suggesting the common representation of $\mathrm{mAb}$ binding epitopes in both 146 and 12S (Figure 4). In acid method, a strong acid $(1 \mathrm{~N} \mathrm{HCl})$ and a weak acid $\left(0.5 \mathrm{M} \mathrm{NaH} \mathrm{NO}_{4}\right)$ were used for 
conversion of $146 \mathrm{~S}$ into $12 \mathrm{~S}$. In case of $10 \%$ $\mathrm{v} / \mathrm{v}$ of $1 \mathrm{~N} \mathrm{HCl}$ method there is little reduction in the reactivity of all $\mathrm{mAbs}$ in comparison to that of heat method and weak acid methods. The reduction in reactivity may possibly due to relative loss of antigenicity of $12 \mathrm{~S}$ subunits by strong acid nature of $\mathrm{HCl}$ (Fig. 3). In weak acid method, $0.5 \mathrm{M} \mathrm{NaH}{ }_{2} \mathrm{PO}_{4} \mathrm{pH}$ 4.5-5.0 was used. The $12 \mathrm{~S}$ subunits synthesized by weak acid treatment and the untreated 146S antigens, both are recognized equally by all $\mathrm{mAbs}$ and the results are highly correlated with that of heat method. However, a combination of strong acid treatment along with heating of $146 \mathrm{~S}$ antigen at $56^{\circ} \mathrm{C}$ for 15 minutes resulted in complete loss of reactivity of all mAbs with that antigen. This possibly may occur due to strong acid nature of $\mathrm{HCl}$ in combination with heat aggravate the complete denaturation of proteins, that resulted in loss of antigenicity of the $12 \mathrm{~S}$ subunits (Fig. 4A and 4B). On comparison of all methods, the strong acid method is not an ideal method of conversion of $146 \mathrm{~S}$ antigen into $12 \mathrm{~S}$ subunits, as it was causing complete denaturation of capsid proteins of virion. Hence, during characterization of monoclonals where it involves the preparation of $12 \mathrm{~S}$ subunits by strong acid method may mislead to false results. In such instances, one may consider the $\mathrm{mAb}$ as $146 \mathrm{~S}$ specific, instead of characterizing it as $\mathrm{mAb}$ recognizing both $146 \mathrm{~S}$ as well as $12 \mathrm{~S}$ antigens.

\section{Characterization of $\mathrm{mAbs}$ binding epitopes by using $12 S$ and $146 S$ antigens}

Total 85 monoclonal antibodies developed in the present study were evaluated for their specific recognition of $146 \mathrm{~S}$ antigen and $12 \mathrm{~S}$ antigens in DAS ELISA. All mAbs are reacting equally with both $146 \mathrm{~S}$ and $12 \mathrm{~S}$ antigens prepared by heat method and weak acid method. The results indicated that none of the mAbs are either $146 \mathrm{~S}$ specific or $12 \mathrm{~S}$ specific but reacting with both. Hence it was predicted that all $\mathrm{mAb}$ binding epitopes were commonly shared between $146 \mathrm{~S}$ and $12 \mathrm{~S}$ antigens.

In developing country like India, the control and eradication of foot and mouth disease is only by vaccination of susceptible animals with inactivated FMDV vaccine. The success of vaccination is largely depends on intactness of the $146 \mathrm{~S}$ antigen. The whole virion particle $(146 \mathrm{~S})$ is highly immunogenic and dissociation of $146 \mathrm{~S}$ antigen into $12 \mathrm{~S}$ subunits resulted in poor immunogenicity (Doel et al., 1982). The quality control analysis involving the identification of $146 \mathrm{~S}$ antigen requires the use of monoclonal antibodies specifically recognizing $146 \mathrm{~S}$ antigen. Hence, there is a need to develop monoclonal antibody which recognizes only the epitopes present on the intact virion particle but not the $12 \mathrm{~S}$ subunits. However, mAbs that specifically detect $146 \mathrm{~S}$ antigens are rarely isolated (Van Maanen et al., 1990; Yang et al., 2008, Harmesen et al., 2017).

The intact virion particle (146S) consists of three capsid proteins viz.VP1, VP2 and VP3 which are exposed on the surface of the capsid. The VP4 capsid protein is located over the internal surface of the capsid. The major physical property of the virus is that mild heating at $56^{\circ} \mathrm{C}$ and lowering the $\mathrm{pH}$ below 6.5 resulted in loss of infectivity of the virus (Randrup 1954). The underlying fact was analyzed in detail by using radioactively labelled purified capsid proteins which evidenced that the four structural proteins encompassing the capsid were transformed into 12 pentameric subunits (New Man and Brown, 1997). The key factors responsible for this dissociation of $146 \mathrm{~S}$ antigen to $12 \mathrm{~S}$ were ratified by X-ray crystallographic studies. The presence of high density of histidine residues at the interface of VP2 and VP3 capsid proteins are involved in dissociation of $146 \mathrm{~S}$ into 12S (Acharya et al., 1989). 
Fig.1 Purification of 146S antigen by cesium chloride ultracentrifugation method

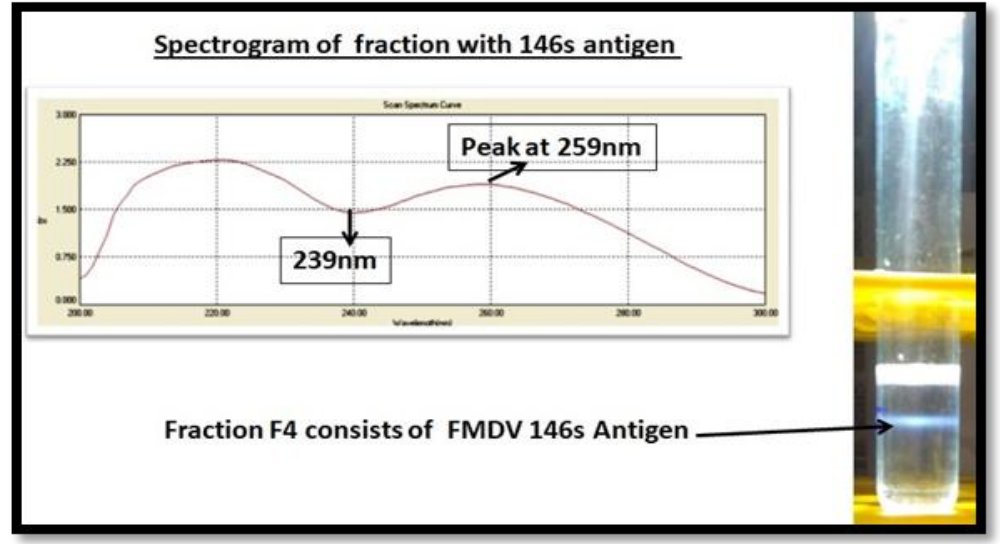

Fig.2 Titration of immunized mice sera in DAS ELISA

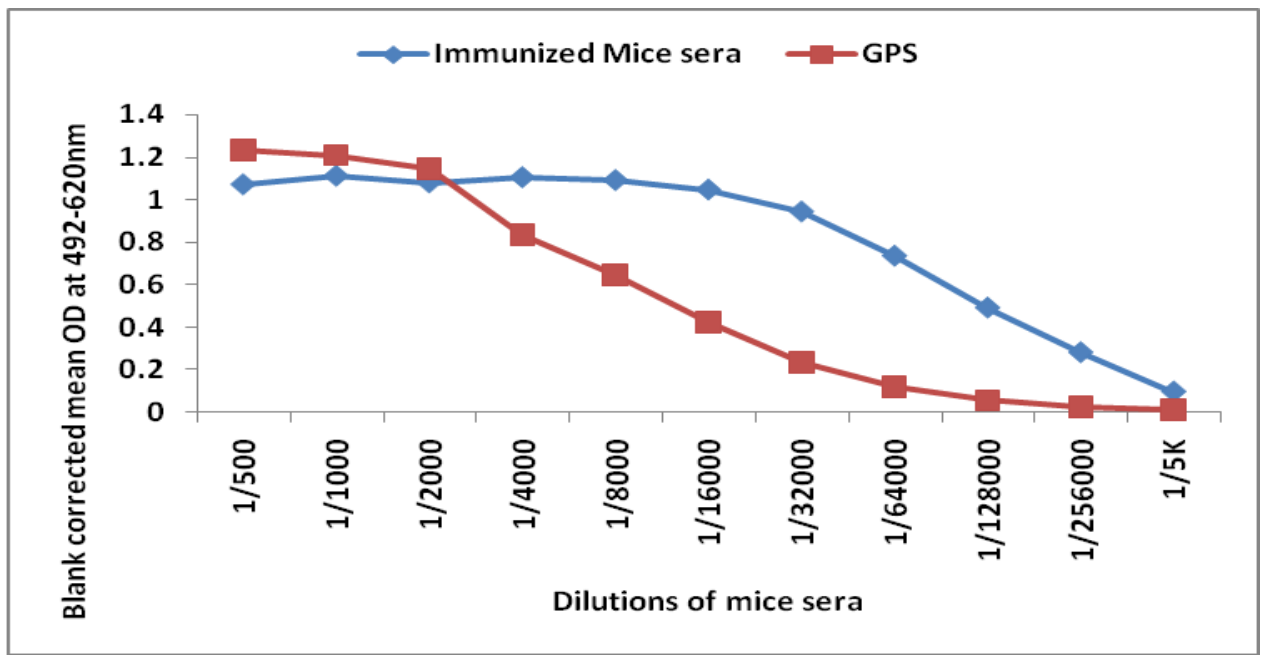

Fig.3A Reactivity of monoclonal antibodies in DAS ELISA with 146S antigen and 12S antigen prepared by different methods

$\square 146 \mathrm{~S}$ antigen $\square 12 \mathrm{~S}$ by $1 \mathrm{~N} \mathrm{HCl}$ method pH $4.5 \approx 12 \mathrm{~S}$ by NaH2PO $4 \mathrm{pH} 4.5 \square 12 \mathrm{~S}$ by Heat method

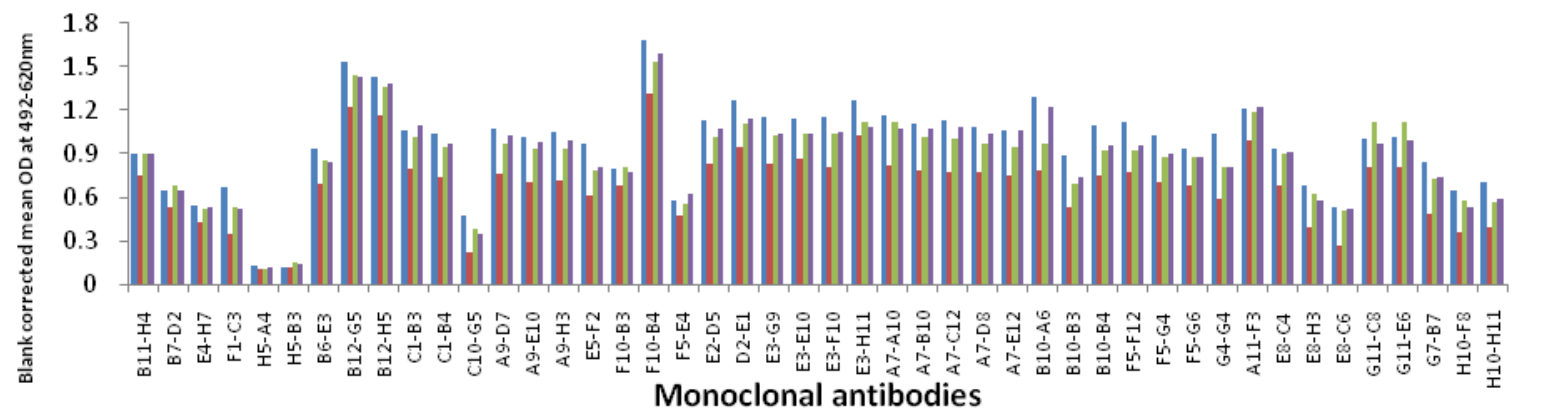


Fig.3B Reactivity of monoclonal antibodies in DAS ELISA with 146S antigen and 12S antigen prepared by different methods

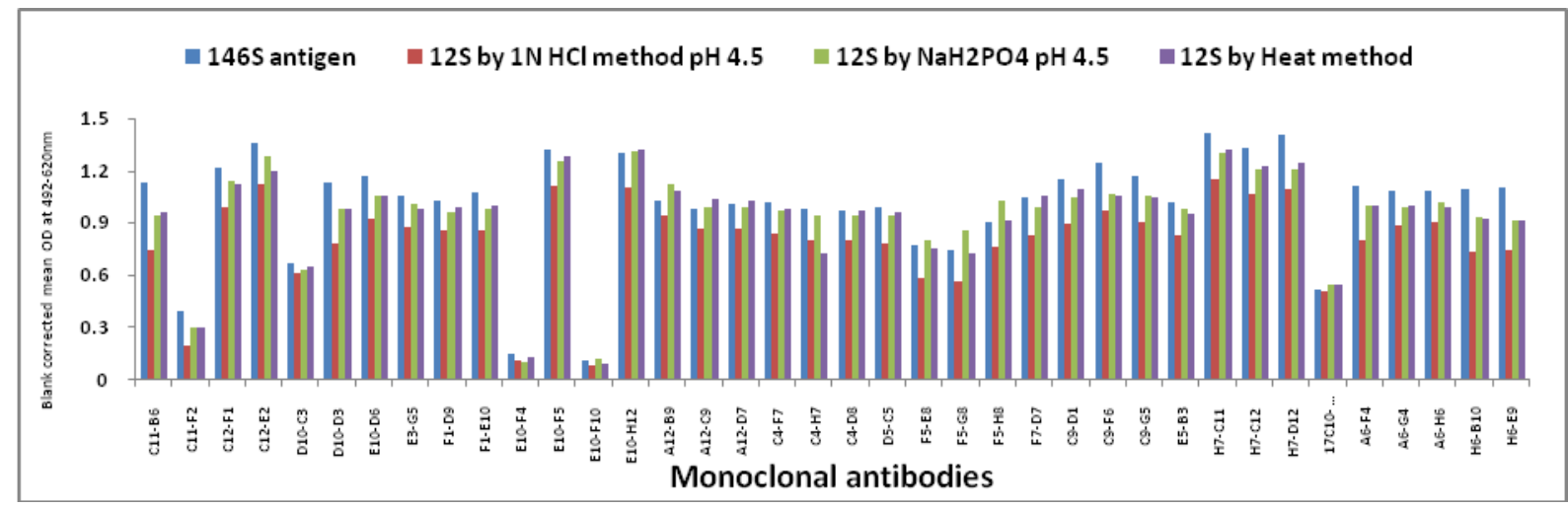

Fig.4A Reactivity of monoclonal antibodies with $146 \mathrm{~S}$ antigen and $12 \mathrm{~S}$ antigens prepared by combination of heat and acid method

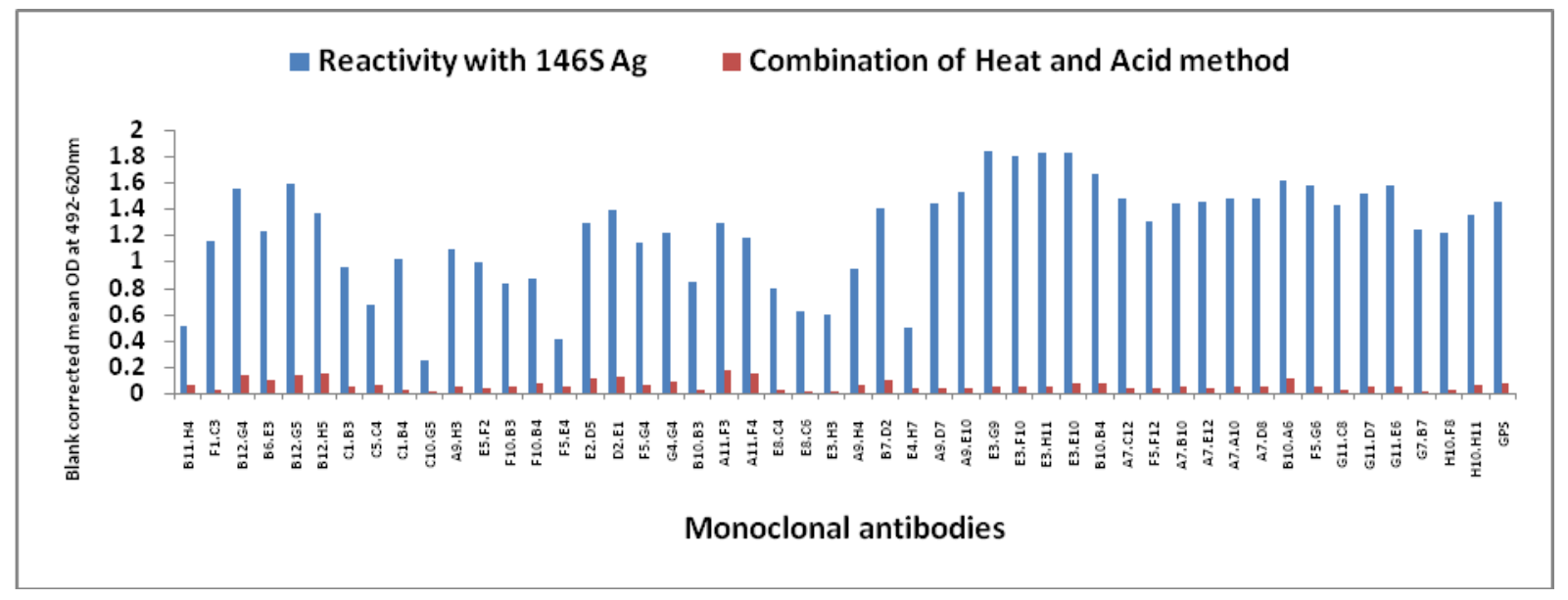

Fig.4B Reactivity of monoclonal antibodies with $146 \mathrm{~S}$ antigen and $12 \mathrm{~S}$ antigens prepared by combination of heat and acid method

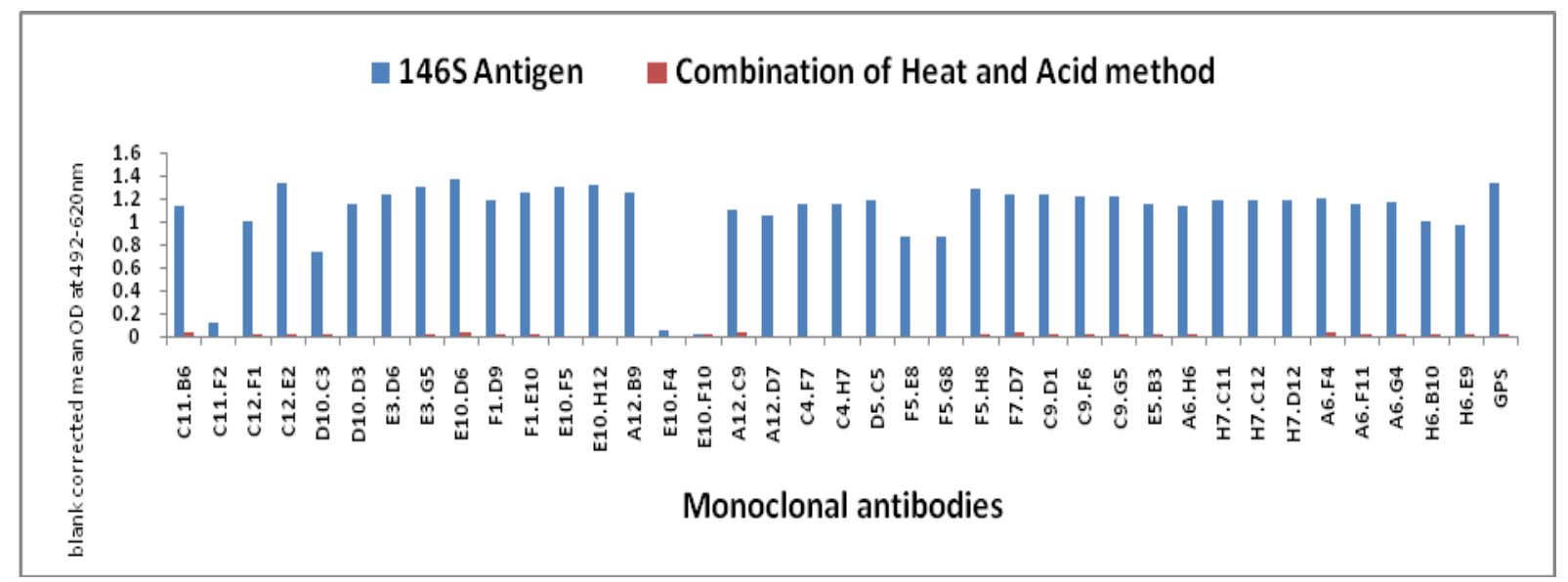


The $\mathrm{pKa}$ of histidine residues is 6.8 , hence the $\mathrm{pH}$ below 6.8 or mild heating enhances the electrostatic repulsion between protonated imidazole side chains. The critical residue histidine was identified at positions VP3-141 and VP3-144 which are oriented at inter protomeric junction in juxtaposition to aspartic acid and glutamic acid on the counter protomer (Twomy et al., 1995). These two residues were identified as potential destabilizers as the numbers of histidine, lysine and arginine residues are greatly exceeding the number of negatively charged aspartic acid and glutamic acid residues on its counter part of the protomer. Later these residues were identified as highly conserved among all the serotypes of FMDV.

In the present study different methods for conversion of $146 \mathrm{~S}$ antigen into $12 \mathrm{~S}$ subunits were compared simultaneously by use of monoclonal antibodies. The strong acid method involves the use of $10 \% \mathrm{v} / \mathrm{v}$ of $1 \mathrm{~N}$ $\mathrm{HCl}$ for conversion of $146 \mathrm{~S}$ into $12 \mathrm{~S}$. Barnett et al., (1989) used strong acid method for preparation of $12 \mathrm{~S}$ subunits and applied these antigens for characterizing the monoclonal antibodies as either 146 specific or $12 \mathrm{~S}$ specific or both. In their experiment characterization of mAbs, they reported that some of the mAbs did not recognize the 12 subunits in sandwich ELISA while poor reactivity with subunits in case of competition ELISA.

In a different study, out of 12 monoclonal antibodies raised against Asia 1, ten were characterized as $146 \mathrm{~S}$ specific and two were characterized as poorly reactive to $12 \mathrm{~S}$ subunits based on the antigens prepared by strong acid method (Sameer et al., 2008). In both of these studies, either absence of reactivity of mAbs or poor reactivity of mAbs with $12 \mathrm{~S}$ subunits is possibly may due to complete denaturation of the antigens by the action of $1 \mathrm{~N} \mathrm{HCl}$. The feasibility of $\mathrm{HCl}$ method for preparation of $12 \mathrm{~S}$ subunits was assessed in the present study. It was revealed that the $\mathrm{pH}$ of strong acid is 4.0 , at which it causes complete denaturation of proteins (Fig. $4 \mathrm{~A}$ and $4 \mathrm{~B}$ ). Instead of using the acid at $\mathrm{pH}$ below 4.0, slight increase in the $\mathrm{pH}$ to 4.5 to 5 resulted in slight increased reactivity of $\mathrm{mAbs}$ with $12 \mathrm{~S}$ subunits but not on par with that of $146 \mathrm{~S}$ antigen (Fig. 3A and 3B). This variation in reactivity of mAbs with antigens treated with $\mathrm{HCl}$ under different $\mathrm{pH}$ conditions, clearly evidenced that the $\mathrm{pH}$ along with strong acidic nature of $\mathrm{HCl}$ has drastic effect on antigenicity of $12 \mathrm{~S}$ subunits. This makes strong acid method is not an appropriate method of conversion of $146 \mathrm{~S}$ to $12 \mathrm{~S}$.

On contrary to strong acid method, the weak acid method was used by many authors for characterization of monoclonal antibodies to FMDV (Crowther et al., 1982; Smit saart et al., 1990; Steve et al., 1986; Rao et al., 1994; Yang et al., 2007). The weak acid 0.2M $\mathrm{NaH}_{2} \mathrm{PO}_{4} \mathrm{pH} 4.4$ was used for preparation of $12 \mathrm{~S}$ subunits from $146 \mathrm{~S}$ antigen of serotype A.

This $12 \mathrm{~S}$ subunits were used for production of a monoclonal antibody that specifically recognizing non neutralizing linear epitope which is conserved among all serotypes (Yang et al., 2007). These earlier reports provided the evidence for feasibility of $\mathrm{NaH}_{2} \mathrm{PO}_{4}$ for effective conversion of $146 \mathrm{~S}$ antigen into $12 \mathrm{~S}$ subunits. Moreover, our present study also revealed that $\mathrm{NaH}_{2} \mathrm{PO}_{4}$ at $\mathrm{pH} 4.5$ can be successfully used for effective conversion of $146 \mathrm{~S}$ antigen into $12 \mathrm{~S}$ subunits.

The heat method involves mild heating of $146 \mathrm{~S}$ antigen at $56^{\circ} \mathrm{C}$ for 1 hour, which results in complete conversion of $146 \mathrm{~S}$ antigen into $12 \mathrm{~S}$ subunits. The Graph 3a \& 3b showed reactivity of all mAbs with $146 \mathrm{~S}$ and $12 \mathrm{~S}$ subunits prepared by heat method. The results indicated that $\mathrm{mAb}$ binding epitopes of all 
these mAbs are commonly represented in both $146 \mathrm{~S}$ and $12 \mathrm{~S}$ subunits. Harmsen et al., (2011) successfully used the heat method for preparation of $12 \mathrm{~S}$ antigen standards for quantifying the antigen concentration in the vaccine. They developed an ELISA with variable heavy chain domains of llamas that specifically recognized either $146 \mathrm{~S}$ or $12 \mathrm{~S}$ particles of Asia-1 serotype (Harmsen et al., 2015). The $146 \mathrm{~S}$ antigen concentration and $12 \mathrm{~S}$ antigen concentration in the vaccine samples were estimated in ELISA by the use of $12 \mathrm{~S}$ antigen standards prepared by heat method and applied in vaccine degradation studies.

In conclusion, all these reports suggested the heat method and weak acid method at $\mathrm{pH} 4.5$ are best methods for conversion of $146 \mathrm{~S}$ antigen into $12 \mathrm{~S}$ and retains the antigenicity of subunits. However, among these two methods heat method is the best one, because in this method no need to add any reagents to the antigen sample and overcome problems associated with $\mathrm{pH}$.

\section{Acknowledgements}

We would like to thank the Director ICARIVRI, Honourable Vice-Chancellor, Sri Vnekateswara Veterinary University, Tirupati and Joint director IVRI, Bengaluru for provision of funding and facilities to carry out the research work. We are sincerely grateful to all the scientific staff associate with the research work.

\section{References}

Acharya, R., Fry, E., Stuart, D., Fox, G., Rowlands, D.J. and Brown, F. 1989. The Three dimensional structure of foot-and-mouth disease virus at $2.9 \mathrm{~A}$ resolution. Nature 337: 709-716.

Barnett P. V., E. J, Ouldridge, Z D. J. Rowlands, F. Brown and N. R. Parry.
Neutralizing Epitopes of Type O Footand-Mouth Disease Virus. I. Identification and Characterization of Three Functionally Independent, Conformational Sites J. gen. Virol. (1989), 70: 1483-1491.

Carrillo, C., Tulman, E. R., Delhon, G., Lu, Z., Carreno, A., Vagnozzi, A. and Rock, D. L. 2005. Comparative genomics of foot-and-mouth disease virus. J. Virol. 79(10): 6487-6504.

Crowther J. R., C. A. Rowe and R. Butcher; Characterization of monoclonal antibodies against a type SAT 2 footand-mouth disease virus. Epidemiol. Infect. (1993), 111: 391-406.

Crowther J.R.; Antigenic structure of footand-mouth disease virus Rev. sci. tech. Off. int. Epiz., 1986, 5 (2): 299-314.

Denoya, C.D. Scodeller, E.A., Vasquez, C., and La Torre, J. 1978. Foot-and-mouth disease virus. Endoribonuclease activity within purified virions. Virology 89: 6774.

Doel, T.R. and Chong, W.K.T. 1982. Comparative immunogenicity of $146 \mathrm{~S}$, $75 \mathrm{~S}$ and $12 \mathrm{~S}$ particles of foot-andmouth disease virus. Arch. Virol. 73(2): 185-91.

Harmsen M.M., H.P.D. Fijten, D.F. Westra, J.M. Coco-Martin. Effect of thiomersal on dissociation of intact (146S) footand-mouth disease virions into $12 \mathrm{~S}$ particles as assessed by novel ELISAs specific for either $146 \mathrm{~S}$ or $12 \mathrm{~S}$ particles Vaccine 29 (2011): 2682-2690.

Harmsen M.M., H.P.D. Fijten, D.F. Westra, A. Dekker; Stabilizing effects of excipients on dissociation of intact (146S)foot-and-mouth disease virions into $12 \mathrm{~S}$ particles during storage as oilemulsion vaccine. Vaccine 33 (2015): 2477-2484

Harmsen MM, Seago J, Perez E, Charleston B, Eblé PL and Dekker A (2017) Isolation of Single-Domain Antibody 
Fragments That Preferentially Detect Intact (146S) Particles of Foot-andMouth Disease Virus for Use in Vaccine Quality Control. Front. Immunol. 8:960. doi: 10.3389/fimmu.2017.00960

Mason, P. W., Pacheco, J. M., Zhao, Q. Z. and Knowles, N. J. 2003. Comparisons of the complete genomes of Asian, African and European isolates of a recent foot-and-mouth disease virus type $\mathrm{O}$ pandemic strain (PanAsia). J. Gen. Virol. 84(6):1583-1593.

McCulloug K. C. and. Butcher; Monoclonal antibodies against foot-and-mouth disease virus $146 \mathrm{~S}$ and $12 \mathrm{~S}$ Partieles Archives of Virology 74, (1982): 1-9.

New Man, J.F.E., and Brown, F. 1997. Footand-mouth disease virus and poliovirus particles contain proteins of the replication complex. J. Virol. 71: 7657 7662.

Randrup, A. 1954. On the stability of footand-mouth disease virus dependent on $\mathrm{pH}$. Investigations on the complement fi xing and the immunizing antigen as well as on the infective agent. Acta Path. Et Microbiol. Scand. 35: 388-395.

Rao M.G, G. Butchaiah, A.K. Sen Antibody response to $146 \mathrm{~S}$ particle, $12 \mathrm{~S}$ protein subunit and isolated VP1 polypeptide of foot-andmouth disease virus type Asia-1 Veterinary Microbiology 39 (1994): 135-143.

Samir Kumar Rana, Tamishraha Bagchi; Development and characterization of monoclonal antibodies against FMD virus type Asia- 1 and determination of antigenic variations in the field strains; Veterinary Immunology and Immunopathology 122 (2008): 241-249

Sangar, D.V., Rowlands, D. J., Cavanagh, D., Brown, F. 1976. Characterization of the minor polypeptides in the foot-and- mouth disease particle. J. Gen. Virol. 31: 35-46.

Smitsaart Eliana N., Juan C. Saiz, Ronald J. Yedloutschnig and Donald O. Morgan; Detection of foot-and-mouth disease virus by competitive ELISA using a monoclonal antibody specific for the $12 \mathrm{~S}$ protein subunit from six of the seven serotypes. Veterinary Immunology and immunopathology, 26 (1990): 251-265.

Stave J. W., J. L. Card and D. O. Morgan; Analysis of Foot-and-Mouth Disease Virus Type O 1 Brugge Neutralization Epitopes Using Monoclonal Antibodies. J. gen. Virol. (1986), 67: 2083-2092.

Twomey, T., France, L.L., Hassard, S., Burrage, T.C., Newman, J.F.E., and Brown, F. 1995. Characterization of an acid-resistant mutant of foot-and-mouth disease virus. Virology 206: 69-75.

Van Maanen C, Terpstra C. Quantification of intact $146 \mathrm{~S}$ foot-and-mouth disease antigen for vaccine production by a double antibody sandwich ELISA using monoclonal antibodies. Biologicals (1990) 18(4): 315-9. doi:10.1016/10451056(90)90036-Y

Yang M, Holland H, Clavijo A. Production of monoclonal antibodies against whole virus particles of foot-and-mouth disease virus serotype $\mathrm{O}$ and $\mathrm{A}$ and their potential use in quantification of intact virus for vaccine manufacture. Vaccine (2008) 26(27-28):3377-82. doi:10.1016/j.vaccine.2008. 04.062

Yang, M., Clavijo, A., Suarez-Banmann, R. and Avalo, R. 2007. Production and characterization of two serotype independent monoclonal antibodies against foot-and-mouth disease virus. Vet. Immunol Immunopathol. 115(1): 126-134. 


\section{How to cite this article:}

Gollapalli Sivarama Krishna, S. Shanmuganathan, R. Manikandan, Madhusudhan Hosamani, V. Bhanuprakash, R.P. Tamilselvan, Suresh H. Basagoudanavar, Anikhet Sanyal and Sreenivasa, B.P. 2019. Evaluation of Different Methods for Conversion of Whole Virion Particle (146S) of FMDV into 12S Subunits and Application in Characterization of Monoclonal Antibodies. Int.J.Curr.Microbiol.App.Sci. 8(08): 1392-1402.

doi: https://doi.org/10.20546/ijcmas.2019.808.162 